\title{
Interest Rate as a Policy Instrument - Recent Experience of Sri Lanka
}

\author{
Dr. W. M. Hemachandra
}

\begin{abstract}
Interest rate is used as a monetary policy instrument in most countries. Sri Lanka too, uses interest rates as one of the policy instruments to achieve the objectives of the Central Bank. In this paper, the relationships between policy rates and other macroeconomic variables are identified and empirical estimations are carried out to find out to what extent the interest rates could be used to manage macroeconomic variables, based on which some policy implications are suggested.
\end{abstract}

\section{Introduction}

Interest rate which is expressed in percentage terms, is a fee paid on borrowed capital. In other words, it is a fee attached to financial instruments. Many Central Banks use the interest rate both as a source of information in determining policies and as an operating instrument for conducting monetary policy. Interest rate mechanism, among other instruments, is used for achieving objectives of the Central Bank. The objectives of the Central Bank of Sri Lanka (CBSL) are to maintain economic and price stability and to maintain financial system stability.

According to classical theory, savings are generally invested through an interest rate mechanism. When savings are equal to investment, the equilibrium rate of interest is determined. It assumes a positive relationship between interest rate and savings and an inverse relationship between the interest rate and investment. One of the major policy instruments in the classical theory is interest rate. 
In the Keynesian theory, the interest rate may not determine the equilibrium level of savings and investment. The process of interest rate determination was regarded as a monetary phenomenon and the interest rate is purely a monetary phenomenon in the Keynesian's version. In this version, low interest rates were advocated to raise income. A large number of developing countries followed these policies until McKinnon and Shaw in 1973 presented their findings, recognising high interest rates.

Liberalization policies which came later did not allow controls on interest rates. McKinnon and Shaw presented a strong case against the low interest rate policy as advocated by neo-classsical and Keynesian paradigms. According to framework of McKinnon and Shaw, the interest rate is positively associated with the savings, investment and economic growth. They assumed an increase in interest rates stimulates savings, especially bank deposits and thereby provides more investible funds thus leading to economic growth. They advocated the removal of interest rate ceilings.

Neo-structuralists expects a substitution effect to come from curb market loans to deposits when the deposit rates are raised, and therefore increasing the interest rate is likely to reduce rate of economic growth by reducing the availability of credit.

Later on market failure school related equilibrium rate of interest to asymmetry of information. In this version, the government has to intervene to rectify market malpractices. Therefore, market failure school suggests to have a government intervention in determining interest rates and efficient allocation of resources.

The use of interest rate as a monetary policy instrument was intensified along with active open market operations (OMO) started in Sri Lanka in 2003. Prior to that, the Central Bank's main policy instruments were the Bank Rate, Statutory Reserve Requirement (SRR) and moral suasion. The interest rate at OMO is a short-term policy instrument, which is used to achieve monetary policy targets, although the behaviour of interest rate has long-term repercussions on macroeconomic variables such as savings, investment, economic growth and inflation.

Under the OMO system, monetary policy operations are conducted to achieve a path of reserve money targets while maintaining short-term interest rates stable around a level which is consistent with the reserve money targets. CBSL manages market liquidity actively through OMO. The interest rate corridor formed by overnight repurchase (Repo) rate and the reverse repurchase (Reverse Repo) is the instrument used to achieve the reserve money targets. If the reserve money is not consistent with the targets the corridor is adjusted upward or downward depending on the requirements. Daily auctions at OMO are used to maintain comparable overnight interest rates. If the CBSL absorbs more liquidity through OMO, overnight auction rates would go up while the reverse will happen when the CBSL 
absorbs less liquidity. Therefore, maintaining liquidity in the market is essential to maintain a stable short-term interest rate. The changes in the liquidity levels would reflect in the changes in the market rates which would take place depending on liquidity management through OMO.

Currently, OMO, through which daily short-term interest rates are determined, are used as one of the most effective instruments in achieving monetary policy targets, and thereby as an instrument to control inflation so as to maintain price stability. Interest rates for overnight repurchase (Repo) and the reverse repurchase (Reverse Repo) are called Central Bank's policy rates. The boundaries of these two rates form an interest rate corridor of which the lower end is the repo rate and the upper end is the reverse repo rate.

The ultimate aim of the management of policy rates is to maintain reserve money as expected by influencing the aggregate demand of the economy. When there is a tight monetary policy, the policy rates adjusted upward, and thereby to reduce aggregate demand, which in turn reducing the demand pull inflation leading to reduce overall inflation.

The interest rate is an instrument available to a Central Bank to achieve reserve money targets which is determined by the bahaviour of Net Domestic Assets (NDA) and Net Foreign Assets (NFA).

At present, the CBSL uses reserve money as the operational target with money supply $\left(\mathrm{M}_{2}\right)$ as an intermediate target in achieving price stability. It is assumed that inflation could be controlled by controlling money supply in this way. The aim of conducting OMO while adjusting interest rates is to achieve the monetary targets, i.e., reserve money. OMO interest rates are expected to influence the market interest rate structure and thereby control credit to government and the private sector which are components of NDA.

In the recent decades, there have been few years when there was a somewhat relaxed monetary policy prevailed. Since 1981, when open market operations were started, 1984, 1986, 1987, $1995-1998,2001-2003$ were the years in which relaxed monetary policy was prevailed. These relaxations were warranted due to favourable domestic and external economic conditions that the country faced. All other years after 1981, there was a tight monetary policy in Sri Lanka and policy rates were adjusted upward accordingly.

The CBSL, since November 2004, has been implementing a tight monetary policy, as one of the measures to control rising inflation. The interest rate corridor was revised upward starting from November 2004 following which market interest rates also increased.

Changes in the policy rates have influenced the behaviour of macroeconomic variables. The objective of this paper is to evaluate to what extent the interest rate is 
responsible in managing price stability and other macro economic variables in Sri Lanka. In this study, Section 2 is devoted to explain the behaviour of interest rates in the recent past and its impact on macroeconomic variables in Sri Lanka. Section 3, through an empirical estimation, attempts to ascertain the effects of policy interest rates on long term interest rates (securities market), credit of the banks, aggregate demand and to comment on the relationships between the variables. The same section carries an analysis on the effect of interest rates on long-term macroeconomic variables such as savings, investment, and growth. Section 4 draws attention to policy implications based on the results of empirical estimations. Section 5 concludes by summarizing findings of the research.

\section{Behaviour of Interest Rates in the Recent Past}

Prior to commencement interest rate corridor along with OMO in 2003, the CBSL used Bank Rate and interest rates at secondary market as policy rates. In addition to these policy rates, market interest rates were determined on the basis of rates on the government securities primary market. Interest rates in the long-term market were guided by the rates of medium and long-term credit fund schemes operated by the Central Bank and those of rupee securities market. The effectiveness of the Bank rate as a monetary policy instrument diminished as a result of existence of interest rates at OMO. OMO rates (policy rates) were one of the determinants of market interest rates. The market rates changed as a result of changes in the repo/reverse repo rates fixed by the CBSL from time to time. Short term market interest rates were fluctuated with the changes in the overnight repo and reverse repo rates of Treasury bills at the secondary market window. Since 1997, Treasury Bonds became one of the determinants of the long term rates structure in the market. Introduction of Treasury Bonds to the market paved the way for a market based interest rate structure for long term instruments, deviating from the basis of long term rates of standard rupee securities market hitherto existed. Table 1 gives the information on policy rates and market rates in the recent past. 
Interest Rate as a Policy Instrument - Recent Experience of Sri Lanka?

Table 1 - Interest Rates in the Recent Past

(per cent per annum)

\begin{tabular}{|c|c|c|c|c|c|c|c|}
\hline \multirow{3}{*}{ Date } & \multicolumn{5}{|c|}{ Policy Rates } & \multirow{2}{*}{\multicolumn{2}{|c|}{ Market Rates }} \\
\hline & \multirow[b]{2}{*}{ Bank Rate } & \multicolumn{2}{|c|}{$\mathrm{OMO}$} & \multicolumn{2}{|c|}{ Medium \& Long Term Rates } & & \\
\hline & & REPO & $\begin{array}{c}\text { Reverse } \\
\text { REPO }\end{array}$ & Rupee Loan & $\begin{array}{l}\text { T-Bonds * } \\
\text { (2 Years) }\end{array}$ & AWDR & WALR \\
\hline 31 Dec 2002 & 18.000 & 9.750 & 11.750 & 13.000 & 11.860 & 7.470 & 12.170 \\
\hline 07 Jan 2003 & 18.000 & 9.000 & 11.000 & 11.000 & 10.120 & 7.180 & 11.420 \\
\hline 09 May 2003 & 18.000 & 8.250 & 10.250 & 11.000 & 10.120 & 6.140 & 10.780 \\
\hline 15 Aug 2003 & 15.000 & 7.500 & 9.500 & 8.000 & 10.120 & 5.660 & 10.040 \\
\hline 16 Oct 2003 & 15.000 & 7.000 & 8.500 & 8.000 & 10.120 & 5.430 & 9.140 \\
\hline 12 Nov 2004 & 15.000 & 7.500 & 9.000 & 8.900 & 8.270 & 5.120 & 9.850 \\
\hline 13 May 2005 & 15.000 & 7.750 & 9.250 & 9.150 & 9.300 & 5.430 & 10.190 \\
\hline 15 Jun 2005 & 15.000 & 8.250 & 9.750 & 9.150 & 10.320 & 5.450 & 10.600 \\
\hline 13 Sep 2005 & 15.000 & 8.500 & 10.000 & 10.600 & 10.390 & 5.840 & 11.510 \\
\hline 22 Dec 2005 & 15.000 & 8.750 & 10.250 & 11.000 & 10.390 & 6.240 & 12.140 \\
\hline 16 Jun 2006 & 15.000 & 9.000 & 10.500 & 10.600 & 11.220 & 6.610 & 12.280 \\
\hline 24 Jul 2006 & 15.000 & 9.125 & 10.625 & 10.600 & 11.220 & 6.590 & 12.620 \\
\hline 28 Sep 2006 & 15.000 & 9.625 & 11.125 & 10.600 & 11.050 & 6.890 & 13.580 \\
\hline 15 Dec 2006 & 15.000 & 10.000 & 11.500 & 10.600 & 12.920 & 7.600 & 14.740 \\
\hline 23 Feb 2007 & 15.000 & 10.500 & 12.000 & 10.600 & 14.070 & 8.180 & 15.350 \\
\hline 31 Dec 2007 & 15.000 & 10.500 & 12.000 & 18.400 & 15.500 & 10.310 & 17.000 \\
\hline
\end{tabular}

* Primary Market rates

Source: Central Bank of Sri Lanka

The CBSL increased policy rates (overnight repo/reverse repo rates) from 7.00 per cent p.a. and 8.50 per cent per annum in 2003 to be 10.50 per cent p.a. and 12.00 per cent p.a. in 2007, respectively. Following these, the market rates also shifted. For instance, the Weighted Average Deposit Rate (AWDR) increased from 5.43 per cent p.a. in 2003 to 10.31 per cent p.a. in 2007. Similarly, the Weighted Average Lending Rate (WALR) increased from 9.14 per cent p.a. in 2003 to 17.00 per cent p.a. in 2007 . Not only the short term rates but also the long term interest rates increased. For instance, the two-year primary market rate for Treasury Bonds increased from 8.27 per cent p.a. in 2004 to 15.50 per cent p.a. in October 2007. In the Section 3 of this paper, the empirical estimations in this regard have been reported. Figure 1 presents the behaviour of some of these interest rates in the recent past. 
Figure 1 - Call Rates, Policy Rates, Auction Rates

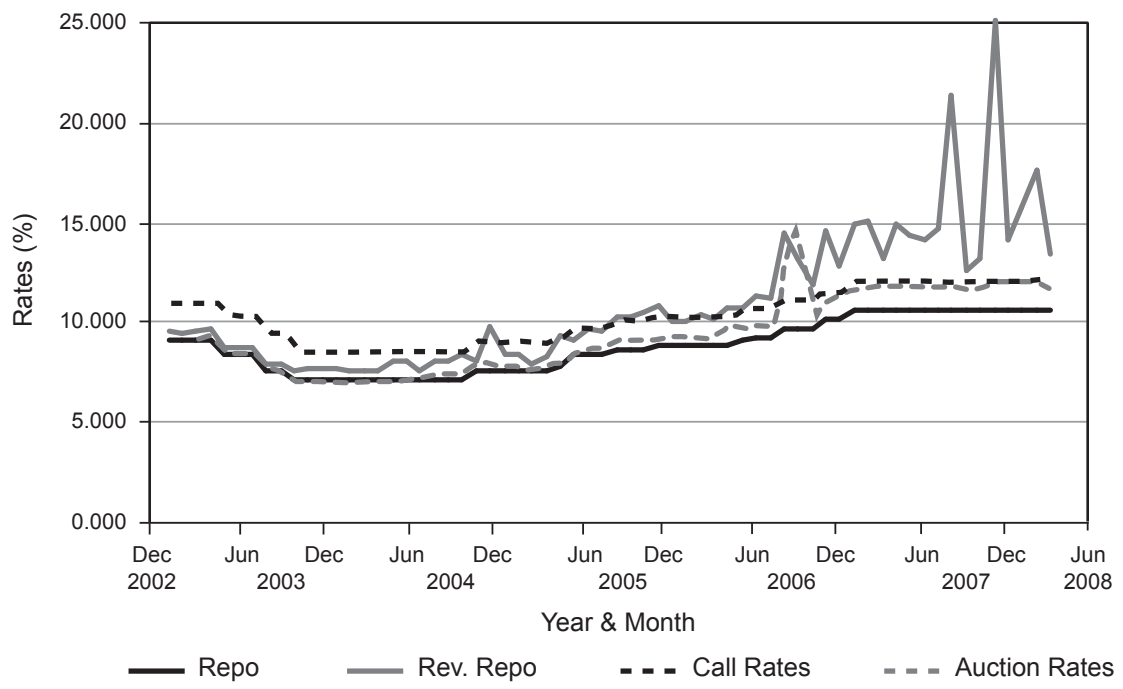

Although the market rates have been higher than the reverse repo rates of the CBSL, the rates of daily secondary market auctions behaved within the corridor. The auction rates were closer to reverse repo rates (which is the upper bound of the corridor) reflecting the tightness of the money market. The difference between the market rates and the policy rates can be attributed to many reasons such as cost of funds, nature of instrument, regulations such as SRR and limits, liquidity levels of the market, maturity period of the financial instrument, transaction size, level of government borrowing, seasonality, preferences of the market and taxation. These other factors have contributed to exist different market rates compared to policy rates.

Coupled with other reasons, the CBSL has been able to achieve the reserve money targets in the recent past, based on the tight monetary policy. Specially, in the first quarter of 2008, monthly actual reserve money has been within the target expected, showing a positive response to demand management policies. Figure 2 shows the behaviour of actual reserve money as against the expected targets. This is one of the favourable outcomes of the tight monetary policy. 
Figure 2 - Reserve Money - Targets Vs Actuals

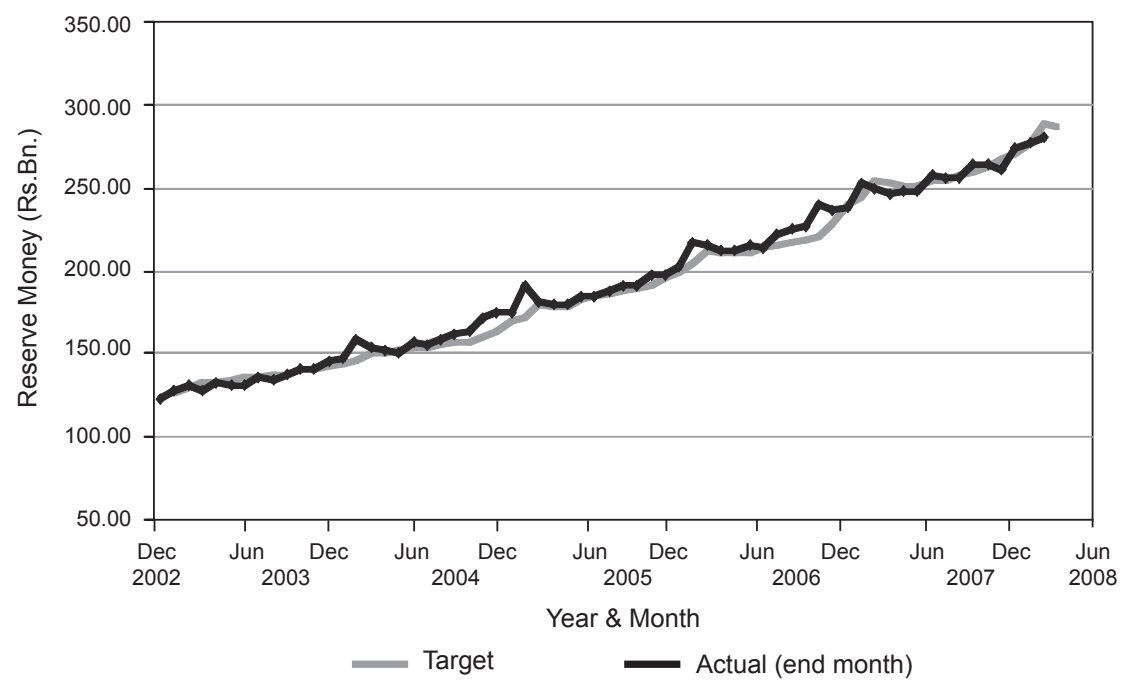

Following the downward adjustments in the reserve money growth, the growth of broad money supply $\left(\mathrm{M}_{2}\right)$ has also declined in the first quarter of 2008. This is also a positive result of the tight monetary policy. Figure 3 shows the growth of broad money supply during the recent past. It shows that broad money was higher than that was expected prior to 2008, but during the first quarter 2008 it has been below the targets, satisfying the expectations.

Figure 3 - Growth of Money Supply

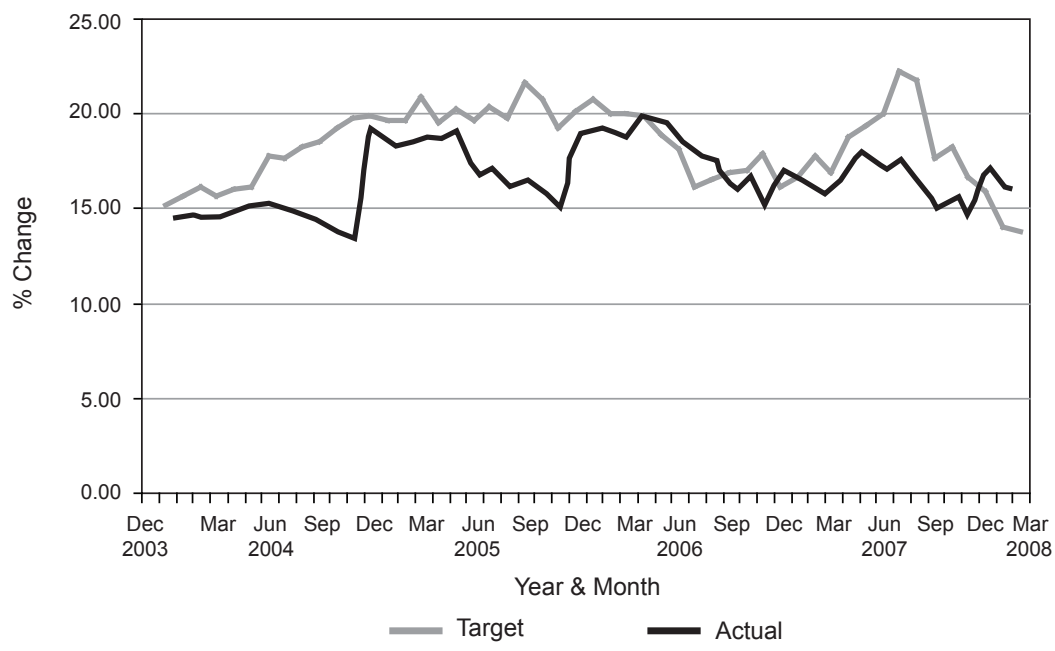


Following these developments in the monetary conditions, credit granted by commercial banks has decreased during the first quarter of 2008 compared to the same period in 2007. Figure 4 shows the declining trend of commercial bank credit to private sector which has happened due to tight monetary policy of the Central Bank.

Figure 4 - Credit Disbursed by Commercial Banks

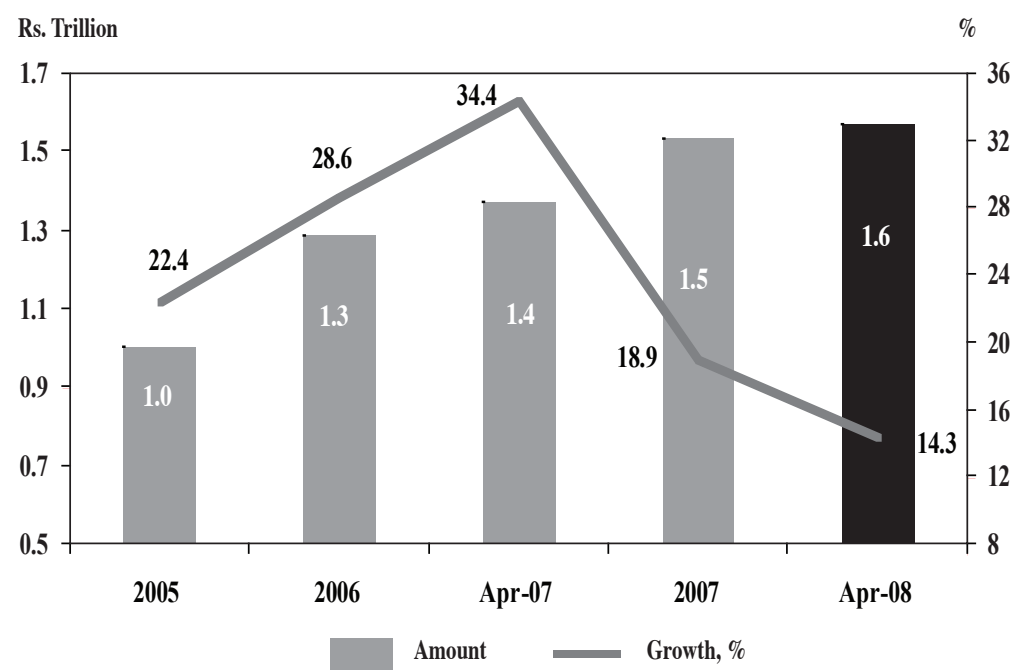

The tight monetary policy has resulted in a decline in the aggregate demand. For instane, increase in real domestic aggregate demand as measured by consumption plus investment in 2007 was 13.6 per cent compared to 20.5 in 2006. Therefore, a conclusion can be made as to following the tight monetary policy Central Bank has been able to achieve its monetary targets.

On the other hand, interest rate is one of the determinants of savings and investment. Savings are expected to increase due to increase in interest rates which in turn will provide investable funds. According to historical data, real interest rates in Sri Lanka have been negative for many years. However, the savings levels of the country have behaved irrespective of the behaviour of interest rates. It appears that domestic savings have no response to the changes in interest rates. Mostly, savings of Sri Lankans are low both due to high proportion of consumption out of the income and low income. In addition to these, domestic savings do not respond to the interest rates due to other reasons such as existence of contractual savings and social habits, which do not respond to interest rates. However, it is to be noted that financial savings (bank deposits) are responding to the changes in interest rates. 
A similar conclusion can be made in regard to investment as well. It is found that financial investments (based on credit of banks) have responded to increased interest rates. Borrowings from banks have responded negatively to increase in interest rates in the recent past. However, long term total domestic investment has not responded to varying interest rates. Investment, other than financial investment (credit from banks) has not behaved according to the changes in short-term interest rates in Sri Lanka.

Figure 5 depicts the behaviour of real interest rates, savings ratios and investment ratios of the country. Accordingly, the savings ratio (DSR) and the investment ratio (IR) have behaved irrespective of real interest rates (i.e., Fixed $=$ real interest rate on fixed deposits of commercial banks and Savings = real interest rate on savings deposits of commercial banks).

Figure 5 - Trends in Real Deposit Rates, Domestic Savings Ratio (DSR) and Investment Ratio (IR)

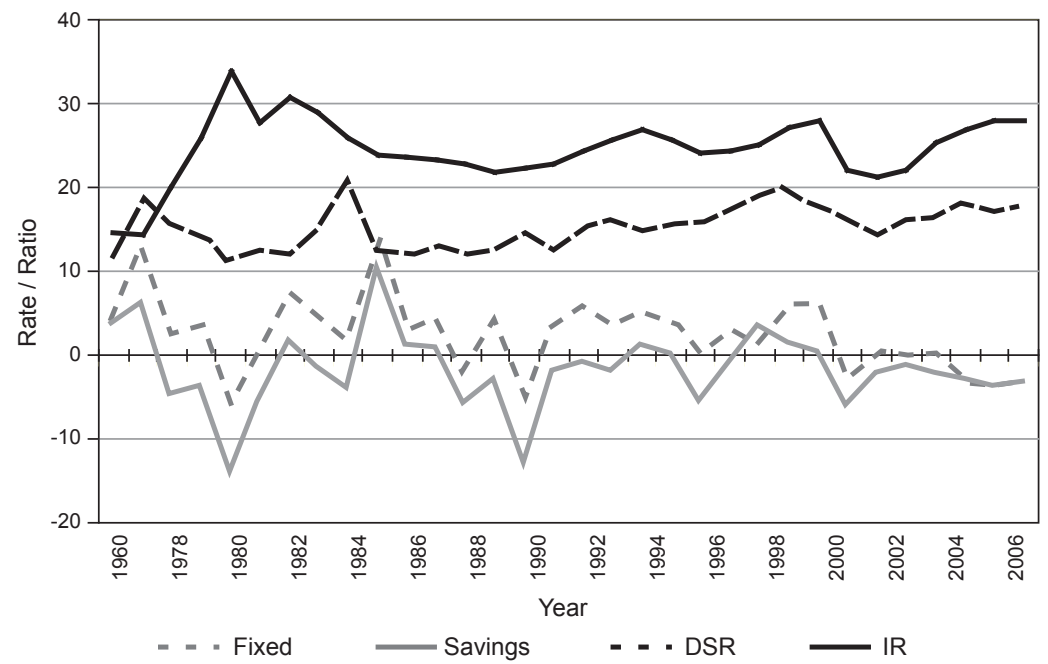

\section{Empirical Estimations \& Analysis}

A series of OLS estimations was carried out to find out the relationships among selected macroeconomic variables discussed in the previous sections. The hypotheses tested are given below. The study period is from 1978 to 2008. Monthly data used for estimations on short-term effects are for the period from February 2003 to May 2008 whilst for long-term effects annual data from 1978 to 2007 are used. 
Table 2 - Hypotheses Tested

\begin{tabular}{|c|c|c|}
\hline & Hypothesis & Status \\
\hline 1. & Policy rates of the Central Bank are positively influencing long-term interest rates. & Confirmed* \\
\hline 2. & Policy rates have a positive effect on bank deposit rates. & Confirmed* \\
\hline 3. & Policy rates have a positive effect on deposits of banks. & Not confirmed ${ }^{*}$ \\
\hline 4. & Interest rates have a positive effect on deposits of banks. & Confirmed* \\
\hline 5. & Interest rates have a positive effect on domestic savings / private savings. & Not Confirmed ${ }^{* *}$ \\
\hline 6. & Interest rates are negatively impacting on total investment. & Not Confirmed ${ }^{* *}$ \\
\hline 7. & Lending rates have a negative effect on private investment. & Confirmed ${ }^{* *}$ \\
\hline 8. & Increase in interest rates reduces credit to private sector. & Confirmed* \\
\hline 9. & Increase in policy rates of the Central Bank leads to reduce aggregate demand. & Not Confirmed ${ }^{*}$ \\
\hline 10. & Aggregate demand is influenced by consumption and total investment / private investment. & Confirmed ${ }^{* *}$ \\
\hline 11. & Investment has a positive impact on economic growth. & Confirmed $^{* *}$ \\
\hline 12. & Policy rates have a positive impact on inflation. & Not confirmed* \\
\hline
\end{tabular}

* Monthly data from February 2003 to May 2008 were used for estimation.

** Annual data from 1978 to 2007 were used for estimation.

\section{The following are the relationships tested ( $t$ statistics are given in parentheses).}

(1) Relationship between Policy Rates and Long-Term Interest Rates Equation Tested

$$
\begin{aligned}
& \text { TBOND }=-0.5871+1.1978 \mathrm{PR}+0.8601 \mathrm{AR}(1) \\
& (-0.19) \quad(3.77) \quad(9.80) \\
& \mathrm{R}^{2}=0.93 \quad \text { D.W. }=2.18
\end{aligned}
$$

According to the equation, policy rates are highly significant in determining the long-term interest rates as measured by two year Treasury Bond rates. As shown in the equation, one percentage point increase in the policy rates will increase Treasury Bond rate by 1.20 percentage points. Therefore, policy rates in Sri Lanka contributes to changes in long-term interest rates i.e., Treasury Bond rates. 


\section{(2) Relationship between Policy Rates and Commercial Bank Deposit Rates}

\section{Equation Tested}

(i) AWDR

$$
=-4.0978+0.4453 \mathrm{PR}+0.6915 \mathrm{PR}_{-1}
$$

$$
\mathrm{R}^{2}=0.87 \quad \text { D.W. }=0.19
$$

(ii)

$$
\begin{aligned}
& \text { REALAWDR }=-2.3147+0.6590 \text { REALPR + 0.2661 REALPR }-1 \\
& (-1.99) \quad(6.72) \\
& \text { + 1.0866 AR (1) - 0.1356 AR (2) } \\
& \text { (7.14) } \quad(-0.83) \\
& \mathrm{R}^{2}=0.99 \quad \text { D.W. }=2.03
\end{aligned}
$$

Policy Rates will influence in determining commercial bank deposit rates. According to the equation, rather than current policy rates, previous periods policy rates affect current deposit rates of the commercial banks. One percentage point increase in previous period policy rates will increase current weighted average deposit rate by 0.69 percentage points. On this basis not the current policy rates but historical policy rates will affect for AWDR.

In the equation (ii), the effect of real policy rates on real interest rate has been tested. Accordingly, real policy rates will influence in determining real average deposit rates. One percentage point increase in the real policy rates will increase real average deposit rate by 0.65 percentage points.

\section{(3) Relationship between Policy Rates and Deposits of Banks}

\section{Equation Tested}

$$
\text { QM }=\begin{array}{ccc}
-1038.341+712.0760 \mathrm{PR}-1179.691 \mathrm{PR}_{-1}+1.0245 \mathrm{QM}_{-1} \\
(-0.20) & (0.25) & (-0.44)
\end{array}
$$

$\mathrm{R}^{2}=0.99 \quad$ D.W. $=1.84$

According to this equation, the policy rates do not influence the total deposits of the banks. However, increase in total deposits in the previous period will influence the total deposits in the current period. 


\section{(4) Relationship between Interest Rates and Deposits}

(i) Weighted Average Deposit Rates

\section{Equation Tested}

$$
\begin{aligned}
& \mathrm{QM}=-280.7368+6342.897 \mathrm{AWDR}-6774.733 \mathrm{AWDR}_{-1}+1.0199 \mathrm{QM}_{-1} \\
& (-0.10) \quad(1.67) \quad(-1.92) \quad \text { (107.76) } \\
& \mathrm{R}^{2}=0.99 \quad \text { D.W. }=2.05
\end{aligned}
$$

According to this equation in determining financial savings i.e., deposits of commercial banks, there is no strong influence from the interest rates. As seen from the equation, the average deposit rate is significant at 10 per cent level and thus, there is some influence from interest rate to deposits of the banks. In addition, the previous trends of the deposits will also be a factor that determines the current level of deposits of commercial banks.

\section{(ii) Fixed Deposit Rates}

\section{Equation Tested}

$$
\begin{aligned}
& \mathrm{QM}=3094043.0+4171.15 \mathrm{FR}+1.3387 \mathrm{AR}(1)-0.189 \mathrm{AR}(2)-0.150 \mathrm{AR}(3) \\
& \begin{array}{llll}
(0.28) & (2.24) \quad(8.45) \quad(-0.76) \quad(-0.90)
\end{array} \\
& \mathrm{R}^{2}=0.99 \quad \text { D.W. }=1.97
\end{aligned}
$$

This equation tests the relationship between fixed deposits rates and the total deposits. Accordingly, one percentage point increase in the fixed deposit rates will increase Rs. 4,171 million quasi money.

\section{(iii) Savings Deposit Rates}

\section{Equation Tested}

$$
\begin{aligned}
& \mathrm{QM}=54323.32+5965.86 \mathrm{SR}-135.03 \mathrm{SR}_{-1} \\
& \text { (0.35) (3.05) (-0.07) } \\
& \text { + 1.1789 } \mathrm{AR}(1)+0.222 \mathrm{AR}(2)+0.058 \mathrm{AR}(3) \\
& \begin{array}{lll}
(7.98) & (-0.96) \quad(0.38)
\end{array} \\
& \mathrm{R}^{2}=0.99 \quad \text { D.W. }=1.95
\end{aligned}
$$


This equation tests the influence of the savings deposit rate on total quasi money. Accordingly, one percentage point increase in savings deposit rates will increase total quasi money of the banks by Rs. 5,965.9 million.

\section{(5) Relationship between Deposit Rates and Domestic Savings/Private Savings}

\section{(i) Domestic Savings}

\section{Equation Tested}

$$
\begin{aligned}
& \text { DSGDP }=-7.8689+0.3445 \mathrm{FR}_{-3}+0.0659 \mathrm{PGDP}+0.3684 \mathrm{AR}(1) \\
& \text { (2.37) }
\end{aligned}
$$

This equation tests the relationship between deposit interest rates, and savings ratio. Accordingly, fixed deposit rates will not affect in determining domestic savings as the coefficient is not significant at 5 per cent level. However, one thousand rupees increase in per capita GDP will increase domestic savings ratio by 0.06 percentage point.

(ii) Private Savings

\section{Equation Tested}

$$
\begin{aligned}
\text { PSGDP }= & 22.6652-0.0606 \mathrm{FR}_{-3}-0.0151 \mathrm{PGDP}_{-2}+0.7032 \mathrm{AR}(1) \\
& (1.60) \quad(-0.44) \quad(-0.21) \\
+ & 0.2058 \mathrm{AR}(2) \\
(0.90) & \\
\mathrm{R}^{2}=0.85 & \text { D.W. }=1.90
\end{aligned}
$$

According to the results of this equation, private savings ratio has also no influence from interest rates. Even the changes in per capita income is not significant in determining the private savings ratio. 


\section{(6) Relationship between Interest Rates and Investment}

\section{Equation Tested}

$$
\begin{gathered}
\mathrm{TIGDP}=32.0354+0.31015 \mathrm{LR}-0.5229 \mathrm{TIGDP}_{-1}+1.1166 \mathrm{AR}(1)-0.5790 \mathrm{AR}(2) \\
(4.02)
\end{gathered}
$$

$\mathrm{R}^{2}=0.52 \quad$ D.W. $=2.04$

As seen from this equation, interest rates do not affect in determining the investments/ GDP ratio of the country. As stated in the equation, lending rates are not significant in determining the investment/GDP ratio.

(7) Relationship between Lending Rates and Private Sector Investment

\section{Equation Tested}

$$
\begin{gathered}
\mathrm{PI}=\underset{(1.97) \quad}{84549.57-4203.879} \mathrm{LR}-1.1628 \mathrm{PI}_{-1} \\
\mathrm{R}^{2}=0.99 \quad \text { D.W. }=2.04
\end{gathered}
$$

According to this equation, lending rates of the banks will influence the private sector investment. Lending rates of the commercial banks will reduce private investment. One percentage point increase in lending rates will reduce private sector investment by Rs. 4,203.8 million.

\section{(8) Relationship between Bank Credit and Private Investment}

\section{Equation Tested}

$$
\begin{aligned}
& \text { PIGDP }=11.0456+0.6754 \mathrm{CPGDP}-0.0925 \mathrm{CPGDP}_{-1}-0.0075 \text { PGDP } \\
& \begin{array}{llll}
(1.23) \quad(2.38) & (0.29) \quad(-0.36)
\end{array} \\
& -0.1797 \mathrm{LR}+0.4727 \mathrm{AR}(1)-0.2413 \mathrm{AR}(5) \\
& (-0.57) \quad(3.08) \quad(-1.93)
\end{aligned}
$$

According to the results of this equation, credit to private sector is responsible for private sector investments. One percentage point increase in credit/GDP ratio will 
increase private investment/GDP by 0.68 percentage point concluding that credit to private sector from banks will determine private investment.

\section{(9) Relationship between Lending Rates and Credit to Private Sector}

\section{Equation Tested}

(i) $\mathrm{CP}=401414-3822.75 \mathrm{LR}_{-} 4922.7 \mathrm{LR}_{-1}-6304.78 \mathrm{LR}_{-2}-4366.18 \mathrm{LR}_{-3}$

$$
\begin{array}{llll}
(2.89) \quad(-1.82) \quad(2.08) \quad(-2.62) \quad(-1.98)
\end{array}
$$$$
+0.8522 \mathrm{CP}_{-1}-0.3193 \mathrm{CP}_{-2}+0.8815 \mathrm{AR}(1)-0.4301 \mathrm{AR}(3)
$$

$$
\mathrm{R}^{2}=0.99 \quad \text { D.W. }=2.05
$$

Results of this equation confirm that private sector credit is influenced by the lending rates. The interest rate variable is significant. One percentage point increase in lending rates will decrease credit to private sector by Rs.38,220 million. There is also a lag effect from credit to private sector in determining current credit to private sector. Rs. 1 million increase in previous year's credit will increase current credit to private sector by Rs.0.85 million.

\section{(10) (i) Relationship among Policy Rates, Total Investment, Total Consumption} and Aggregate Demand

\section{Equation Tested}

$$
\begin{aligned}
& \mathrm{AD}=4134.025-650.874 \mathrm{PR}+0.5751 \mathrm{TI}+0.7295 \mathrm{TC}+0.3468 \mathrm{TC}_{-1} \\
& \begin{array}{llll}
(0.60) \quad(-1.54) \quad(9.82) \quad(10.45)
\end{array} \\
& \mathrm{R}^{2}=0.99 \quad \text { D.W. }=2.21
\end{aligned}
$$

This equation tests the relationship among real domestic aggregate demand (as measured by consumption plus investment), policy rates, investment and consumption. Accordingly, policy rates are not responsible in determining aggregate demand of the economy. Total investment and total consumption will influence the aggregate demand. As seen in this equation, Rs. one million increase in total investment will increase Rs. 0.575 million of aggregate demand and Rs. one million increase in total consumption will increase Rs. 0.729 million of aggregate demand. 
(ii) Relationship among Consumption, Private Investment and Aggregate Demand

\section{$\underline{\text { Equation Tested }}$}

$$
\begin{aligned}
& \mathrm{AD}=-912.36+0.8227 \mathrm{TC}+0.4079 \mathrm{PI}+0.8103 \mathrm{M} 2-1
\end{aligned}
$$

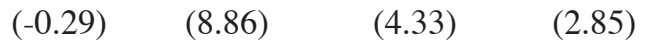

$$
\begin{aligned}
& \mathrm{R}^{2}=0.99 \quad \text { D.W. }=2.22
\end{aligned}
$$

This equation tests the relationship among consumption, private investment and aggregate demand. According to the equation, both private investment and consumption have influenced in determining aggregate demand. As seen from the equation, Rs. one million increase in total consumption will increase aggregate demand by Rs. 0.822 million and Rs. one million increase in private investment will increase aggregate demand by Rs. 0.408 million.

\section{(11) Relationship between Investment and Economic Growth}

\section{Equation Tested}

(i) $\mathrm{YG}=3.159+0.5344 \mathrm{PIGDP}_{-} 0.4404 \mathrm{PIGDP}_{-1}-0.3662 \mathrm{CPGDP}$

$$
\begin{aligned}
& (0.61) \quad(3.09)+(-2.8 \\
& +
\end{aligned}
$$

$$
\mathrm{R}^{2}=0.36 \quad \text { D.W. }=2.09
$$

According to this equation, private sector investments are responsible in determining economic growth. One percentage point increase in private investment/ GDP ratio will increase the economic growth by 0.53 percentage point.

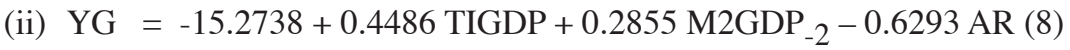

$$
(-2.30)
$$

$$
\mathrm{R}^{2}=0.52 \quad \text { D.W. }=1.99
$$

Total investment has also positively influenced the economic growth. According to this equation, one percentage point increase in total investment 
to GDP ratio will increase economic growth by 0.45 percentage point. Other variable tested in this equation is money supply to GDP ratio which is also significant in determining current economic growth.

\section{(12) Relationship among Policy Rates and Inflation}

\section{Equation Tested}

$$
\begin{aligned}
\mathrm{IN}= & -5.684+0.968 \mathrm{IN}_{-1}+0.5157 \mathrm{PR}-0.5677 \mathrm{PR}_{-1}+0.0644 \mathrm{USD} \\
& (-2.99) \quad(25.29)
\end{aligned}
$$

$$
\mathrm{R}^{2}=0.98 \quad \text { D.W. }=0.41
$$

According to this equation, since the variable is not significant there is no influence from the policy rates in determining inflation. One of the other variables that determines inflation is exchange rate. According to the equation, one rupee increase in the dollar rate will increase inflation by 0.06 percentage point. Other than this, historical inflation rate will influence the current inflation.

\section{Policy Implications}

From the empirical estimations, given in Section 3 a number of hypotheses was tested facilitating to draw conclusions based on the results. According to the empirical analysis, policy interest rates affect positively in determining long-term interest rates. Therefore, whenever there is an increase in the policy rates, there can be a corresponding increase in long-term interest rates. Similarly, policy rates are influencing the interest rate structure of the country. In the estimations, it was seen that the policy rates are influencing in determining savings deposit rates and the fixed deposit rates of the banks. Therefore, whenever there is an increase in policy rates subsequent rate increases in the financial market have to be expected. An increase in the interest rates will increase the cost of borrowings of the government.

Through the empirical estimations, it was also tested the relationship between policy rates and deposits of the commercial banks. Accordingly, policy rates are not influencing level of deposits of the banks thus concluding deposits of the banks are not variable due to changes in the policy rates. This may be due to the fact that policy rates are not changed very often and the deposit rates of banks are varied according to auction rates which are determined based on liquidity levels of the market. However, interest rates of the savings deposits and those of fixed deposits are influential in determining volume of deposits in the 
banks. It was seen from the estimations weighted average deposit rates, fixed deposits rates and the savings deposits rates are responsible in determining total deposits of the banks. Therefore, rather than policy rates, interest rates are important determinants of financial savings i.e., commercial bank deposits in the country. The coefficients for weighted average deposit rates, fixed deposit rates and savings deposit rates are significant in explaining the behaviour of total deposits of the country.

According to the estimations carried out, there is no influence from the interest rates to domestic savings and the private savings of the country. Domestic savings used in the estimation are normally estimated as residuals from the national accounts and they contain both financial savings and other forms of savings. As indicated in the previous Section, interest rates are determinants of financial savings, which are required for investment. Since the domestic savings are residuals derived from the national accounts, they are not determined by the movements of interest rates. Further, domestic savings consist of savings of both government and private sector. Since the government savings are negative and government requirements are funded through borrowed funds they are not varied according to interest rates. Similarly, private savings which also are derived figures in the national accounts have no influence from the interest rates. Interest rate is an instrument in deciding financial savings in the country, but not the total domestic or private savings. Domestic and private savings in the national accounts consist of various other types of savings which may not be necessarily financial. A part of the domestic/private savings emerged from contractual savings which are not decided by interest rates. Accordingly, interest rates as a policy instrument influence the financial savings but not the domestic savings or the private savings, at large. Financial savings which are required for investments can be encouraged by increasing interest rates. In order to promote domestic/private savings changes in other factors such as habits and cultural changes are required.

According to item 6 of Section 3, interest rate is not influencing the total investment of the country as measured by investment/GDP ratio. This may be due to several reasons. Firstly, country's savings finance a part of investment and other sources such as borrowing and foreign direct investment finance the balance. The latter two sources do not depend on interest rates. Larger investment projects in the country are financed from donor funding which are not determined according to interest rates. Secondly, government investments (which is a major part) is not dependent on interest rates. Thirdly, there is a part of private investments, which is not varied based on the interest rate fluctuations. Accordingly, since a substantial part of total investment is not determined by the behaviour of interest rates, total investment is not influenced by interest rate behaviour of the country. However, the private sector investment is behaved based on the interest rates i.e., higher the lending rates the lower the private sector investment. Since a part of the private investments is financed from the credit of the banks, credit of the banks is responsible in deciding private investment 
(item 8 of Section 3). It appears that interest rate is a deciding factor in determining private sector investment since private sector investment are financing through credit. Item 9 of Section 3 indicates that lending rates are a determinant of private sector credit which are used for investment.

Hence, any increase in interest rates will reduce credit and thereby investment. In this way, by changing the interest rate, the policy makers can influence only the private sector investment by managing credit channels but not the total investment in which there is a proportion from the non-private sector, which is not determined on the basis of the interest rates. Hence, only the private sector investment can be influenced through interest rate mechanism in the country.

In the empirical analysis, it was also tested the relationship between the interest rates and the aggregate demand. According to the equation tested, item 10 of Section 3 , the policy rates are not responsible in determining aggregate demand. Therefore, by merely changing the policy rates the aggregate demand cannot be changed. It appears that in order to change aggregate demand, policy instruments other than interest rate have to be used. Some of the policies that can be used are quantitative restrictions, limits on credit, selective credit controls, moral suasions and fiscal policies. According to the equation tested, the total investment and the total consumption are responsible in deciding aggregate demand. Therefore, rather than the policy rates, other measures to control investment and consumption have to be implemented. Since the private sector investment is affected by interest rate increases, inappropriate interest rates increases are harmful for investment. It is required to influence/change consumption patterns of the public in order to manage aggregate demand. Rather than using interest rate in order to manage aggregate demand it is preferable to use other instruments such as Statutory Reserve Requirement (SRR), direct credit controls and moral suation for effective results.

Empirical estimations also tested the relationship between the investment and economic growth. It was clearly seen from the estimations that the total investment as a percentage of GDP is responsible in determining economic growth. Since the interest rate is instrumental in deciding private sector investment which are financed through credit lines of the commercial banks, the interest rate can be used to influence private sector investment through which total investment can be increased/decreased and economic growth targets can be achieved. Appropriate level of interest rates are required since investment can be discouraged due to high interest rates although aggregate demand can be managed and therefore a balanced policy is required. Since the savings are positively related to interest rates by increasing interest rate the savings can be promoted and in this way availability of funds can be increased. 
As seen from the equation tested, there is no influence from the policy rates to inflation. However, inflation increased along with other factors such as depreciation of foreign exchange rates as proxied by dollar rate in the equation. The dollar rate in the equation tested is highly significant in explaining inflation of the country.

\section{Conclusions}

In this study it was attempted to measure the effects of interest rates on macroeconomic variables based on which some policy implications were highlighted. The first section covered the sequences of events took place after increasing the policy interest rates, particularly after 2004. The objective of increasing the policy rates, was to achieve price stability by controlling aggregate demand. In the empirical analysis, it was seen that aggregate demand has not been influenced by changes in the policy rates and therefore other policies as suggested are preferable to manage aggregate demand. It was seen that policy rates changes affect the interest rate structure, i.e., both short-term and long-term rates. It was also revealed that interest rate has not influenced in determining domestic savings and private savings. According to the estimations, total investment has not been influenced by the changes of interest rates. However, private sector investment has an influence from the interest rates since they have been financed by credit of the financial institutions, which has an impact from interest rates. Further, it was recognised that GDP growth is influenced by investment and to achieve economic growth, investment, particularly the private investment has to be encouraged and credit has to be provided. Finally, it was found that the policy rate changes have not directly affected inflation in Sri Lanka. Policies, specially the monetary policy in Sri Lanka have to be decided considering the impacts from the interest rates as identified in the study. 


\section{Variables used in the Study}

Variable

\section{Description}

\section{Monthly Data}

TBOND $=$ Yield Rates of Treasury Bonds (percent p.a.)

PR $\quad=$ Average of maximum and minimum Polity Rates (per cent p.a.)

AWDR = Weighted Average Deposit Rates (per cent p.a.)

REALAWDR $=$ Real Weighted Average Deposit Rates (per cent p.a.)

REALPR = Real Average Policy Rates (per cent p.a.)

$\mathrm{QM}=$ Quasi Money (Rs.mn)

FR $=$ Commercial Bank Interest Rates for 24 months Fixed Deposit Rates (per cent p.a.)

SR $=$ Commercial Bank Interest Rates for Savings (per cent p.a.)

LR = Commercial Bank Lending Rates secured by immovable property (per cent p.a.)

$\mathrm{CP}=$ Credit to private sector by Domestic Banking Units (Rs.mn)

IN $\quad=$ Inflation as measured by changes in CPI (per cent p.a.)

USD = US Dollar/ Rupee Rate (Rs.)

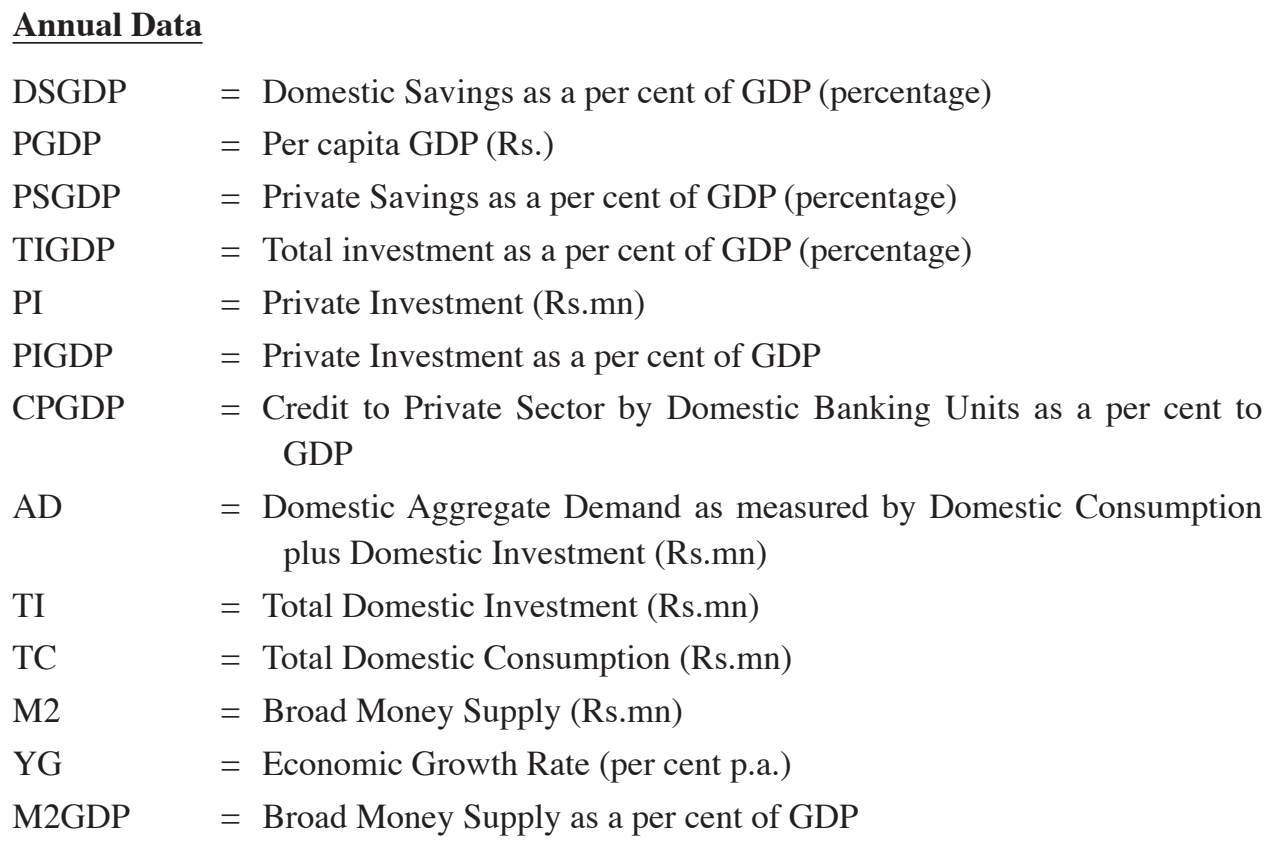




\section{References}

Central Bank of Sri Lanka Annual Report, Various Issues.

Dornbusch, R. and Fischer, S., (1978), "Macro Economics", Mcgraw-Hill Book Company.

Hemachandra W.M. (2005), "Financial Deepening and its implications for the Sri Lankan Economy”, Central Bank of Sri Lanka.

Wijesinghe D.S., (2006), "Active open market operations: A Review of Experience" Central Bank of Sri Lanka, Staff Studies, Vol. 36. No. 1 \& 2 - 2006. 